\title{
Meningkatkan kinerja pemerintah daerah dengan transparansi dan akuntabilitas
}

\author{
${ }^{1)}$ Lutfi Alqurani \\ Lutfialqurani20@gmail.com \\ ${ }^{2)}$ Rahandhika Ivan Adyaksana \\ rahandhika@upy.ac.id \\ ${ }^{1,2)}$ Fakultas Binsis, Prosa Akuntansi, Univesitas PGRI Yogyakarta
}

\begin{abstract}
Local government accountability and performance has become an interesting topic in recent research. This research aims to determine the effect of accountability and transparency on the performance of local governments. The method used in this research is quantitative. The data used was primary and obtained by visiting the location directly (field research) and providing a research questionnaire to the respondent.

The research sample was consisted of employees working in SKPD of Bantul Regency. The sample selection method uses purposive sampling technique. The total sample is 86 respondents who were obtained by distributing questionnaires in 2019. Data were analyzed using multiple linear regression. The variables in this study are accountability, transparency, and government performance. The study results prove that accountability and transparency have a significant and positive effect on government performance.
\end{abstract}

Keywords: accountability; transparency; government performance.

\section{Pendahuluan}

Pelaporan keuangan adalah bentuk nyata kinerja pemerintah dalam memberikan informasi terkait keuangan yang berguna untuk membuat keputusan dalam hal politik, ekonomi dan sosial. Para pengguna informasi keuangan dalam suatu pemerintahan adalah pihak-pihak yang berkepentingan seperti kreditor, investor, pemerintah, dan masyarakat. Laporan keuangan berisi informasi yang dibutuhkan untuk mengetahui beberapa hal, yaitu: apakah operasi keuangan sudah dijalankan dengan baik dan benar, apakah suatu entitas sudah mematuhi hukum dan peraturan yang berlaku, apakah audit entitas telah menyajikan laporan keuangan secara wajar, serta untuk menilai penerapan akuntabilitas dari segi integritas, kinerja, ril, dan pertanggungjawaban aktivitas pemerintah. Laporan keuangan harus diaudit agar dapat memberi informasi yang benar, sehingga dapat digunakan untuk memenuhi kebutuhan para penggunanya (Umar et al., 2018).

Otonomi daerah dilakukan agar reformasi keuangan berjalan sesuai dengan tujuan yang telah ditetapkan. Reformasi keuangan daerah dilaksanakan dalam rangka pengalokasian publik dengan tujuan sebagai alat pengendalian, agar dapat meningkatkan transparansi pemerintah. Pengelolaan keuangan daerah harus dilaksanakan sesuai peraturan perundang-undangan yang berlaku dan memiliki manfaat bagi masyarakat dengan tidak melupakan azas keadilan, azas umum, tertib, transparan, efektif, ekonomis, dan efisien (Nindya, 2016). Akuntabilitas, partisipasi dan transparansi merupakan 3 elemen yang digunakan untuk mengukur kinerja pemerintah. Kinerja pemerintah dikatakan baik jika sudah memenuhi ketiga elemen tersebut. Indonesia merupakan salah satu negara 
berkembang yang masih memiliki masalah terkait akuntabilitas keuangan. Masalah ini, menyebabkan perubahan yang sangat signifikan dalam hal pengelolaan pengeluaran anggaran yang dilakukan oleh pemerintah pusat kepada pemerintah daerah (Salomi, 2015). Akuntabilitas merupakan sebuah hubungan yang dijalin antara dua pihak yaitu pihak pemegang kendali dan pihak yang mengatur entitas dengan pihak yang memiliki kekuatan formal terhadap pihak pemegang kendali. Pemerintah memiliki fungsi untuk menyampaikan informasi kepada masyarakat terkait dengan sumber dana dan sumber daya masyarakat beserta penggunaanya (Made et al., 2015).

Transparansi adalah sebuah bentuk pertanggungjawaban dengan mempublikasikan sebuah informasi yang relevan atas suatu laporan keuangan kepada publik (Haryatmoko, 2011). Penyajian laporan keuangan yang baik, benar serta akurat dan dapat dipertanggungjawabkan kepada publik merupakan sebuah dasar yang digunakan dalam mewujudkan transparansi dan akuntabilitas. Penyajian laporan keuangan pemerintah daerah yang komperehensif merupakan suatu alat ukur yang digunakan untuk menilai tingkat transparansi dan akuntabilitas publik. Laporan keuangan yang kompeten digunakan untuk menjamin terciptanya akuntabilitas sektor publik, serta sebagai alat ukur kinerja finansial pemerintah (Embun \& Widya, 2017).

Sistem pelaporan yang baik dan benar dapat digunakan untuk mengawasi kinerja manajer dalam merealisasikan sebuah anggaran. Dalam Agency Theory, terdapat hubungan keagenan antara masyarakat (principal) dan pemerintah (agent). Pemerintah mempunyai kewajiban untuk menyajikan infromasi yang detail dan transparan agar masyarakat dapat menilai kinerja pemerintah dalam melakukan tugas dan tanggungjawabnya. Untuk meningkatkan akuntabilitas kinerja instansi pemerintah yang baik, diperlukan sistem pelaporan yang baik (Suhesti, 2016). Masyarakat menuntut pemerintah agar memiliki kinerja yang baik sebagai realisasi dari tanggungjawabnya kepada masyarakat, serta sebagai perwujudan otonomi daerah. Kinerja pemeritah merupakan kemampuan seseorang atau kelompok yang dibuktikan dengan hasil kerja. Pengelolaan pemerintahan yang baik dapat memberikan kesejahteraan kepada masyarakat secara keseluruhan dari hasil kerja yang telah dilakukan, sehingga pemerintah mendapat pengakuan secara langsung dari masyarakat atas kinerjanya (Lucy \& Husaini, 2013).

Salah satu hal yang menarik untuk dikaji adalah pengelolaan keuangan daerah yang terjadi di Kabupaten Bantul. Kabupaten Bantul telah dipilih oleh Tim Pusat Kajian Akuntabilitas Keuangan Negara DPR RI sebagai percontohan pengelolaan keuangan. Hal ini disebabkan oleh hasil penilaian BPK yang menemukan bahwa Kabupaten Bantul memiliki tingkat akuntabilitas dan transparansi terbaik (Nurul \& Susmayanti, 2019). Hal tersebut membuat peneliti tertarik untuk mengetahui apakah akuntabilitas dan transparasni berpengaruh terhadap kinerja pemerintah khususnya di kabupaten bantul. Penelitian ini dilakukan untuk mengetahui pengaruh akuntabilitas dan transparansi pengelolaan keuangan daerah terhadap kinerja pemerintah daerah. Penelitian ini di fokuskan pada SKPD di Kabupaten Bantul yang berfungsi untuk melayani masyarakat dalam menyelesaikan atau memenuhi kebutuhan rakyat. Perencanaan keuangan daerah yang dibuat pemerintah harus menerapkan prinsip-prinsip transparansi dan akuntabilitas publik. SKPD harus menerapkan 
prinsip-prinsip akuntabilitas publik dalam melaporkan, menyajikan, dan memberikan pertanggungjawaban, serta mengungkapkan segala bentuk aktivitas dan kegiatan yang menjadi tanggungjawabnya kepada masyarakat. Di sisi lain, transparansi publik lebih menekankan kepada SKPD agar mampu menyajikan dan menyediakan informasi yang cukup relevan, akurat, dan tepat waktu tentang kebijakan publik dan proses pembentukannya kepada masyarakat.

Penelitian mengenai pengaruh akuntabilitas dan transparansi pengelolaan keuangan daerah terhadap kinerja pemerintah daerah pernah dilakukan oleh beberapa peneliti dan belum ditemukan hasil yang konsisten. Auditya et al. (2013); Seri (2015); Setiyawan \& Safri (2016) menyatakan bahwa akuntabilitas berpengaruh terhadap kinerja pemerintah. Namun, pada penelitian yang dilakukan oleh Arifani et al. (2018) dan Turalaki et al. (2017) menemukan hasil bahwa akuntabilitas tidak mempengaruhi kinerja pemerintah. Sedangkan penelitian Umar et al. (2018) membuktikan bahwa transparansi memberikan pengaruh nyata dalam meningkatkan kinerja instansi. Hasil penelitian Turalaki et al. (2017) menemukan bahwa transparansi berpengaruh terhadap kinerja pemerintah. Sedangkan hasil penelitian Porumbescu (2012) dan Bannister \& Connolly (2011) menemukan bahwa transparansi tidak mempengaruhi kinerja pemerintah. Berdasarkan hasil penelitian terdahulu terlihat bahwa hasil penelitian masih belum konsisten, sehingga penelitian ini dilakukan untuk menambah bukti hasil penelitian.

\section{Kajian Literatur dan Pengembangan Hipotesis}

\subsection{Akuntabilitas}

Akuntabilitas (Accountability) adalah sebuah keadaan yang dapat dipertanggungjawabkan. Disisi lain akuntabilitas memberikan informasi serta pengungkapan atas kinerja finansial dan aktivitas yang telah dilakukan kepada pihak-pihak yang berkepentingan. Akuntabilitas juga dapat menggambarkan suatu kejadian nyata dan menjelaskan data yang dapat dipertanggungjawabkan (Rahima, 2017). Akuntabilitas publik merupakan sebuah pertanggungjawaban atas aktivitas yang telah dilakukan oleh pemerintah, sehingga harus dilaporkan kepada DPRD dan masyarakat (Made et al., 2015). Akuntabilitas terdiri dari 2 yaitu, akuntabilitas horizontal dan akuntabilitas vertikal. Akuntabilitas horizontal ialah bentuk pertanggungjawaban pemerintah kepada masyarakat luas, sedangkan akuntabilitas vertikal ialah pengelolaan dan pertanggungjawaban kepada otoritas yang paling tinggi seperti pemerintah pusat kepada MPR, unit pelaksana teknis, pemerintah daerah, dan pemerintah pusat (Agustin, 2017).

\subsection{Transparansi}

Transparansi/ keterbukaan merupakan suatu keputusan yang dilakukan dengan mekanisme sesuai dengan peraturan yang ditetapkan oleh lembaga. Informasi yang berkaitan dengan organisasi disajikan secara transparan, sehingga dapat dengan mudah dan bebas diakses oleh masyarakat yang terkena dampak dari kebijakan yang telah ditetapkan. Untuk informasi yang di "rahasiakan perusahaan" atau informasi yang tidak berhak diakses oleh publik, maka diperlukan kriteria tertentu yang ditetapkan secara jelas. Keterbukaan dapat pula diartikan 
sebagai suatu informasi yang terkait dengan kinerja lembaga dan disajikan melalui media massa, sehingga dapat dipahami/ digunakan oleh masyarakat (Erick et al., 2018).

\subsection{Kinerja}

Kinerja merupakan sebuah pencapaian atau tingkat keberhasilan yang diperoleh suatu instansi atas pekerjaan yang telah dilakukan dengan memanfaatkan sumber daya yang dimiliki (Umar et al., 2018). Terdapat dua pendekatan yang digunakan dalam mengukur kinerja, yaitu dilihat dari aspek kinerja kelompok, dan dilihat dari kinerja organisasi itu sendiri. Organisasi publik erat kaitannya dengan akuntabilitas, kualitas layanan, produktivitas, responsibilitas dan persamaan pelayanan.

\subsection{Perumusan Hipotesis}

Akuntabilitas diperlukan sebagai alat untuk mengukur kinerja organisasi publik dalam meningkatkan pelayanannya kepada masyarakat. Menurut Asrida (2012) semakin baik akuntabilitas dan transparansi dalam suatu organisasi, maka akan semakin baik kinerja anggaran pemerintah daerah. Untuk meningkatkan kinerja keuangan daerah diperlukan akuntablitas dan transparansi. Salah satu aktivitas pemerintah yang harus menerapkan konsep akuntabilitas adalah pengelolaan keuangan. Konsep akuntabilitas mengharuskan pemerintah memberikan pertanggungjawaban kepada publik terkait pelaksanaan pengelolaan pemerintahan yang telah dilakukan. Untuk mewujudkan hal tersebut pemerintah harus menaati peraturan yang telah ditetapkan (Lucy \& Husaini, 2013). Nuraini et al. (2012) menyatakan bahwa pemerintah dapat mewujudkan akuntabilitas yang baik melalui penyajian laporan akuntabilitas kinerja pemerintah (LAKIP) dan penyajian laporan keuangan sesuai peraturan menteri. Beberapa peneliti, Turalaki, et al (2017) dan Arifani et al. (2018) menemukan bahwa akuntabilitas tidak mempengaruhi kinerja pemerintah. Namun, pada penelitian Auditya et al. (2013); Seri (2015); Setiyawan \& Safri (2016) menyatakan bahwa akuntabilitas berpengaruh terhadap kinerja pemerintah.. Peneliti menduga dengan adanya penerapan akuntabilitas yang baik, maka akan meningkatkan kinerja pemerintah secara signifikan. Berdasarkan uraian diatas, maka hipotesis yang dirumuskan adalah sebagai berikut:

\section{$H_{1}$ : Akuntabilitas pengelolaan keuangan berpengaruh positif terhadap kinerja Pemerintah Daerah}

Transparansi adalah menyediakan informasi yang cukup, akurat, tepat waktu, serta mudah diakses tentang kebijakan publik dan proses pembentukannya. Transparansi dapat dikatakan sebagai suatu aturan yang mengupayakan pelaporan atas kebijakan-kebijakan yang berlaku, sehingga informasi terkait kebijakan tersebut mudah diakses dan kredibel (Hari, 2018). Informasi sendiri merupakan sebuah kebutuhan mendasar bagi masyarakat untuk berpartisipasi dalam mengawal dan mengawasi pengelolaan daerah. Penerapan transparansi berpengaruh positif terhadap pengelolaan keuangan daerah, walaupun demikian masih banyak juga SKPD yang masih belum menerapkan transparansi (Lucy \& Husaini, 2013).

Hak masyarakat dalam memperoleh informasi tentang penyelenggaraan pengelolaan keuangan daerah dengan mudah, benar, jujur, adil, dan tidak diskriminatif harus diutamakan 
oleh pemerintah agar dapat meningkatkan kinerja. Hal ini dapat direalisasi dengan penerapan konsep transparansi dalam menjalankan tugas dan tanggungjawabnya sebagai aparat pemerintah. Selain meningkatkan kinerja pemerintah, informasi yang diberikan kepada masyarakat juga membantu dalam mengevaluasi dan menilai pengelolaan keuangan daerah. Hal ini dilakukan agar masyarakat dapat mengawasi kinerja pemerintah, sehingga pemerintah akan bekerja dengan lebih berhati-hati dan sesuai dengan ketentuan yang ada (Lucy \& Husaini, 2013). Beberapa peneliti, Bannister \& Connolly (2011) dan Porumbescu (2012) menemukan bahwa transparansi tidak mempengaruhi kinerja pemerintah. Hanafiah et al. (2016); Made et al. (2015); Turalaki et al. (2017); Umar et al. (2018) menyatakan bahwa transparansi pengelolaan keuangan daerah berpengaruh terhadap kinerja pemerintah. Peneliti menduga dengan adanya penerapan konsep transparansi yang baik, maka akan meningkatkan kinerja pemerintah secara signifikan. Berdasarkan pembahasan yang dilakukan diatas maka hipotesis yang dirumuskan adalah sebagai berikut:

\section{$\mathrm{H}_{2}$ : Transparansi pengelolaan keuangan berpengaruh positif terhadap kinerja Pemerintah Daerah}

\section{Metode Penelitian}

Populasi penelitian adalah seluruh pegawai yang berada di SKPD pada Kabupaten Bantul dengan jumlah SKPD adalah 29 unit. Jenis data yang digunakan adalah data primer yang diperoleh dengan memberikan kuesioner penelitian kepada responden. Responden penelitian adalah pegawai pada seluruh SKPD sesuai dengan kriteria yang diperlukan. Teknik pengambilan sampel menggunakan purposive sampling yaitu berdasarkan kriteria dan pertimbangan tertentu yang telah ditentukan peneliti. Kriteria sampel yang digunakan dalam penelitian adalah pegawai yang menduduki jabatan kepala dinas, bendahara serta sekretaris yang ada di SKPD Kabupaten Bantul. Kriteria yang telah ditentukan dengan pertimbangan setiap kriteria mempunyai fungsi dan tanggungjawabnya secara berkesinambungan dan berhubungan dengan kinerja tiap-tiap SKPD. Kepala dinas bertanggungjawab terkait kinerja karyawan serta pengelolaan keuangan dan keputusan dalam suatu organisasi sedangkan sekretaris dan bendahara bersama-sama merancang agenda dalam mengupayakan pencairan dan penggalian sumber dana bagi aktifitas dan operasional dan program organisasi. Seluruh instrumen pada kuesioner menggunakan pertanyaan dengan jawaban skala likert dari 1 (sangat tidak setuju) sampai dengan 5 (sangat setuju).

\subsection{Definisi Operasional Variabel}

Akuntabilitas adalah penyampaian pertanggungjawaban dengan menjawab serta menerangkan kinerja dan tindakan kepada badan hukum/ seseorang/ pimpinan kolektif sebuah organisasi dan pihak yang mempunyai wewenang dan hak guna meminta keterangan akan pertanggungjawabannya. Transparansi yang dilakukan pemerintah guna membuktikan kepada masyarakat bahwa pemerintah dalam pengelolaan keuangan telah sesuai dan mematuhi aturan perundag-undangan dan jujur (Nasution, 2018). Kinerja merupakan hasil kerja yang dilakukan dan telah mendapatkan sebuah pengakuan bahwa kinerja yang didapat dari hasil kerja telah sesuai dengan target (Umar et al., 2018). Akuntabilitas dan transparansi merupakan variabel independen sedangkan kinerja merupakan variabel dependen. 
Tabel 1: Instrumen Penelitian

\begin{tabular}{|c|c|}
\hline Variabel & Instrumen \\
\hline Akuntabilitas & $\begin{array}{l}\text { 1. Tugas dilaksanakan dengan baik } \\
\text { 2. Hukum/sanksi } \\
\text { 3. Pelayanan lebih baik } \\
\text { 4. Tanggung jawab dan tepat waktu }\end{array}$ \\
\hline Transparansi & $\begin{array}{ll}\text { 1. } & \text { Aksesibilitas } \\
\text { 2. } & \text { Publikasi } \\
\text { 3. } & \text { Keterbukaan }\end{array}$ \\
\hline Kinerja & $\begin{array}{l}\text { 1. Hasil yang dicapai dari perilaku anggota organisasi } \\
\text { 2. Keberhasilan sebuah organisasi } \\
\text { 3. Pencapaian dari organisasi }\end{array}$ \\
\hline
\end{tabular}

Sumber: Umar et al. (2018)

\section{Hasil Penelitian}

Berdasarkan hasil penyebaran kuesoner diperoleh 86 kuesioner yang dapat digunakan sebagaialat analisis. Hasil analisis pada diskripsi responden penelitian ditunjukkan pada tabel 2. Responden dengan jenis kelamin laki-laki berjumlah 45 dengan tingkat persentase sebesar $52 \%$ sedangkan masa kerja paling banyak adalah $>10$ tahun yaitu 45\%. Berdasarkan tingkat pendidikan, responden terbesar adalah responden yang memiliki latar belakang pendidikan sarjana yaitu sebesar 52\%. Berdasarkan jabatan responden, responden paling banyak menduduki jabatan kepala dinas dan bendahara yaitu sebesar $66 \%$.

Setelah dilakukan analisis terhadap diskripsi responden, selanjutnya dilakukan analisis atau pengujian pada data berupa kesioner. Pengujian kuesioner menggunakan uji validitas dan reliabilitas. Pengujian validitas menggunakan pearson correlation dengan taraf signifikansi sebesar $5 \%$. Contoh hasil pengujian validitas pada variabel kinerja disajikan pada tabel 3.

Tabel 2: Profil Responden

\begin{tabular}{clcc}
\hline No. & Keterangan & Jumlah & Persentase \\
\hline 1 & JenisKelamin & & \\
& Laki-laki & 41 & $48 \%$ \\
& Perempuan & 45 & $52 \%$ \\
& Total & $\mathbf{8 6}$ & $\mathbf{1 0 0 \%}$ \\
\hline 2 & Pendidikan & 10 & $12,5 \%$ \\
& SMA/SMK & 10 & $12,5 \%$ \\
& Diploma & 48 & $52,5 \%$ \\
& Sarjana & 18 & $22,5 \%$ \\
& Magister & $\mathbf{8 6}$ & $\mathbf{1 0 0 \%}$ \\
& Total & & $33,7 \%$ \\
\hline 3 & Jabatan & 29 & $32,6 \%$ \\
& Kepala Dinas & 28 & $33,7 \%$ \\
& Sekretaris & 29 & $\mathbf{1 0 0 \%}$ \\
& Bendahara & $\mathbf{8 6}$ & \\
& Total & & $45,3 \%$ \\
\hline 4 & Masa Kerja & 39 & $16,3 \%$ \\
& $>10$ tahun & 14 & $9,3 \%$ \\
& 5-10 tahun & 8 & $29,1 \%$ \\
& <1 tahun & 25 & $\mathbf{1 0 0 \%}$ \\
\hline
\end{tabular}


Tabel 3. Validitas Variabel Kinerja Pemerintah (Y)

\begin{tabular}{ccccc}
\hline Variabel & No. & Korelasi & Sig (2-tailed) & Ket. \\
\hline & Y1 & 0,796 & $0,000^{* *}$ & Valid \\
& Y2 & 0,723 & $0,000^{* *}$ & Valid \\
& Y3 & 0,804 & $0,000^{* *}$ & Valid \\
Kinerja & Y4 & 0,760 & $0,000^{* *}$ & Valid \\
Pemerintah & Y5 & 0,826 & $0,000^{* *}$ & Valid \\
& Y6 & 0,667 & $0,000^{* *}$ & Valid \\
& Y7 & 0,652 & $0,000^{* *}$ & Valid \\
& Y8 & 0,745 & $0,000^{* *}$ & Valid \\
& Y9 & 0,879 & $0,000^{* *}$ & Valid \\
& Y10 & 0,839 & $0,000^{* *}$ & Valid \\
\hline
\end{tabular}

Keterangan: ** $\operatorname{sig}<1 \%$

Setelah dilakukan uji validitas instrumen penelitian, langkah selanjutnya adalah pengujian reliabilitas. Pengujian reliabilitas menggunakan cronbach alpha dengan batas cutoff 0.6. hasil pengujian cronbach alpha ditujukkan pada tabel 4 .

Tabel 4. Uji Reliabilitas

\begin{tabular}{ccccc}
\hline Variabel & $\begin{array}{c}\text { Croncbach's } \\
\text { Alpha }\end{array}$ & Cut off & N Off Item & Keterangan \\
\hline Akuntabilitas & 925 & $>0,6$ & 12 & Reliabel \\
Transparansi & 911 & $>0,6$ & 12 & Reliabel \\
Kinerja Pemerintah Daerah & 923 & $>0,6$ & 10 & Reliabel \\
\hline
\end{tabular}

Tabel 5. Uji hipotesis

\begin{tabular}{cccc}
\hline Variabel & $\mathrm{B}$ & $\mathrm{t}$ & P value \\
\hline (constanta) & 16,043 & 4,280 & $0,000^{* *}$ \\
Akuntabilitas & 0,338 & 3,511 & $0,001^{*}$ \\
Transparansi & 0,173 & 2,095 & $0,039^{*}$ \\
\hline F hitung $=24,468$ & & & $0,000^{* *}$ \\
Adusted $R$ Square $=0,356$ & &
\end{tabular}

Hasil pengujian hipotesis (Tabel 5) membuktikan bahwa akuntabilitas berpengaruh secara signifikan terhadap kinerja pemerintah Kabupaten Bantul. Oleh karena itu, dapat disimpulkan bahwa akuntabilitas dapat meningkatkan rasa tanggungjawab pemerintah terhadap tugas yang diberikan serta meningkatkan kinerja pemerintah khususnya dalam pengelolaan keuangan pemerintah daerah. Hasil penelitian ini mendukung penelitian Auditya et al. (2013); Seri (2015); Setiyawan \& Safri (2016). Akuntabilitas dapat menjadi bukti kepada masyarakat bahwa pemerintah telah menjalankan tugas dengan baik dan sesuai keinginan rakyat (Nasution, 2018). Dengan menjalankan asas Akuntabilitas sebagai kewajiban pihak pemegang amanah maka kinerja pemerintah dapat dipertanggungjawabkan. Pemerintah harus memberikan pertanggungjawaban, menyajikan, melaporkan dan mengungkapkan segala aktifitas dan kegiatan yang menjadi tanggungjawabnya agar kualitas kinerja pemerintah daerah menjadi lebih baik guna mendorong terwujudnya good governance.

Hasil pengujian hipotesis telah membuktikan bahwa transparansi berpengaruh secara signifikan terhadap kinerja pemerintah Kabupaten Bantul. Oleh karena itu, dapat disimpulkan bahwa transparansi pada SKPD Bantul akan membuat pengelolaan keuangan semakin baik, sehingga berdampak pada peningkatan kinerja pemerintah secara 
berkesinambangun dan secara keseluruhan. Hasil penelitian ini mendukung penelitian Made et al. (2015); Turalaki et al. (2017); dan Umar et al. (2018). Penerapan konsep transparansi menyebabkan ketersediaan informasi bagi publik yang dapat diakses dengan mudah, cepat, dan murah, sehingga memenuhi hak tiap individu untuk memperoleh informasi yang sama. Secara teoritis pemerintah harus memperhatikan dua aspek transparansi, yaitu komunikasi antara pemerintah dengan publik, dan hak masyarakat terhadap akses informasi. Penerapan konsep transparansi akan memudahkan publik untuk memperoleh informasi, sehingga hak tiap individu yang membutuhkan informasi tersebut akan terpenuhi. Hal ini berdampak pada peningkatan kepuasan masyarakat terhadap pelayanan pemerintah, sehingga kinerja pemerintah menjadi lebih baik.

\section{Kesimpulan, Keterbatasan dan Saran}

Kesimpulan dari penelitian ini adalah akuntabilitas dan transparansi berpengaruh signifikan terhadap kinerja pemerintah daerah. Berdasarkan hasil penelitian diperoleh bebrapa keterbatasan sehingga dapat digunakan sebagai masukan untuk penelitian selanjutnya. Keterbatasan tersebut adalah jumlah sampel penelitian ini hanya terbatas pada pegawai di SKPD Kabupaten Bantul, sehingga jumlah sampel masih sedikit. Penelitian selanjutnya dapat memperluas populasi dengan menambahkan masyarakat yang menggunakan pelayanan publik karena masyarakat juga memperhatikan akuntabilitas, transparansi dan kinerja pemerintah (Arifani et al., 2018).

\section{Daftar Pustaka}

Arifani, C., Salle, A., \& Rante, A. (2018). Pengaruh akuntabilitas, transparansi dan pengawasan terhadap kinerja anggaran berbasis value for money (Studi empiris pada Pemerintah Kota Jayapura). Jurnal Akuntansi \& Keuangan Daerah, 13, 68-82.

Asrida. (2012). Pengaruh penerapan prinsip akuntabilitas dan transparansi keuangan terhadap kinerja penyusunan anggaran pada pemerintah Kabupaten Bireuen. Jurnal Kebangsaan, 1(1), 30-40.

Auditya, L., Husaini, \& Lismawati. (2013). Analisis pengaruh akuntabilitas dan transparansi pengelolaan keuangan daerah terhadap kinerja pemerintah daerah. Jurnal Fairness, 3 nomor 1, 21-41.

Agustin, R. D. (2017). Konsep value for money dalam mengukur kinerja pelayanan sektor publik. Jurnal Ilmu dan Riset Akuntansi, 6(6), 1-15.

Bannister, F., \& Connolly, R. (2011). The Trouble with Transparency: A Critical Review of policy and internet, 8(1), 8-17.

Embun, \& Widya, S. (2017). Pengaruh sistem pengendalian intern, penyajian laporan keuangan, aksesabilitas laporan keuangan dan gaya kepemimpinan terhadap transparansi dan akuntabilitas pengelolaan keuangan daerah di Kabupaten Indragiri Hulu. JOM Fekon. 4(1) 572-585.

Erick, T. P., David, P. S., \& Winston, P. (2018). Pengaruh pengawasan, akuntabilitas dan transparansi keuangan. Jurnal Riset Akuntansi Going Concern, 13(3),74-85.

Haryatmoko. (2011). Etika publik untuk integritas pejabat publik dan politisi . Jakarta: PT. Gramedia Pustaka Utama, Kompas Gramedia Building.

Hanafiah, R., Syukriy, A., \& Saputra, M. (2016). Pengaruh akuntabilitas, transparansi, kapasitas sumber daya manusia, dan pengawasan intern terhadap pengelolaan keuangan daerah. (Studi di SKPK Pemerintah Kabupaten Aceh Utara). jurnal Akuntansi, 5(4), 84-95. 
Hari, S. (2018). Analisis pengaruh transparansi, akuntabilitas dan pemanfaatan sistem informasi akuntansi keuangan daerah terhadap pengelolaan APBD. Jurnal ekobistek, 7(1), 91-100.

Lucy, A., \& Husaini, L. (2013). Analisis pengaruh akuntabilitas dan transparansi pengelolaan keuangan daerah terhadap kinerja pemerintah daerah. Jurnal Fairness, 13 (1), 59-75.

Made, B. S., Gede, A. Y., \& Nyoman, A. S. (2015). Pengaruh pengawasan keuangan daerah, akuntabilitas dan transparansi pengelolaan keuangan daerah terhadap kinerja pemerintah daerah Kabupaten Buleleng. E-Journal Universitas Pendidikan Ganesha Jurusan Akuntansi, 3(1), 1-12.

Nasution, D. A. (2018). Analisis pengaruh pengelolaan keuangan daerah, akuntabilitas dan transparansi terhadap kinerja keuangan pemerintah. Jurnal Studi Akuntansi dan Keuangan, 2(3), 149-162.

Nuraini, Y., Titi , S., \& Rahman, A. (2012). Model pengelolaan keuangan instansi dalam mewujudkan transparansi dan akuntabilitas keuangan negara. Jurnal Ekonomi dan Bisnis, 11(01), 57-66.

Nurul F, A., \& Susmayanti, H. (2019). Bantul Jadi Contoh Transparansi Keuangan Desa, Dinilai Sukses Jalan Sistem Keuangan Desa. Yogyakarta: Tribun Jogja. Retrieved from https://www.google.com/amp/s/jogja.tribunnews.com/amp/2019/01/16/bantuljadi-contoh-transparansi-keuangan-desa-dinilai-sukses-jalan-sistem-keuangan-desa

Nindya, U. (2016). Pengaruh sistem pengendalian pemerintah intern pemerintah, kinerja pegawai, pengawasan melekat dan pengawasan fungsional terhadap efektivitas pengelolaan keuangan daerah. JOM Fekon, 3(1), 911-923.

Ni Luh, P. P., \& Ni Made, Y. L. (2017). Pengaruh akuntabilitas, transparansi, dan partisipasi anggaran terhadap kinerja anggaran pada pemerintah Kota Denpasar. E-Jurnal Akuntansi Universitas Udayana, 8(3), 2451-2476.

Porumbescu, G. A. (2012). Does transparency improve citizens' perceptions of government performance? Evidence from Seoul. Administration \& Society, 49(3).

Rahima, B. P. (2017). Pengaruh penerapan sistem akuntansi keuangan daerah, transparansi publik dan aktivitas pengendalian terhadap akuntabilitas keuangan daerah Kabupaten Tanah Datar. Jurnal Akuntansi dan Publik, 8(3), 102-115.

Salomi, J. H. (2015). Pengaruh penyajian laporan keuangan daerah dan aksesabilitas laporan keuangan daerah terhadap transparansi dan akuntabilitas pengelolaan keuangan daerah kota Ambon. 2nd CBAM (Conference in Business, Accounting, and Management) World Class Islamic University, Sultan Agung Islamic 2(1), 82-95.

Setiyawan, H. E., \& Safri, M. (2016). analisis pengaruh akuntabilitas publik, ransparansi publik dan pengawasan terhadap kinerja satuan kerja perangkat daerah di Kabupaten Bungo. Jurnal Perspektif Pembiayaan dan Pembangunan Daerah, 4(1), 69-77.

Suhesti, S. R. (2016). Pengaruh kejelasan sasaran anggaran, pengendalian akuntansi dan sistem pelaporan terhadap akuntabilitas kinerja instansi pemerintah. Jurnal Ekonomi, 3(1), 705-719.

Seri, S. (2015). The effect of performance-based budgetting implementation towards the institution performance accaountbility. Jurnal Information Management and Bussines Review, 7(4), 21-33.

Turalaki, S., Tinangon, J. J., \& Wokas, H. R. (2017). Pengaruh akuntabilitas dan transparansi publik terhadap kinerja pelayanan di Dinas Pendapatan Kabupaten Minahasa Selatan. Jurnal EMBA, 5, 1182-1192. 
Umar, Z., Syawalina, C. F., \& Khairunnisa. (2018). Pengaruh akuntabilitas dan transparansi pengelolaan keuangan daerah terhadap kinerja Instansi Inspektorat Aceh. Kolegial, 6(2), 136-148. 